\title{
PERENCANAAN SISTEM PENYALURAN AIR LIMBAH DOMESTIK KOTA BOGOR MENGGUNAKAN AIR HUJAN UNTUK DEBIT PENGGELONTORAN (Planning of Domestic Wastewater Sewerage in Bogor City Using Rainwater for Flushing Flowrate)
}

\author{
Allen Kurniawan* dan Nura Adithia Dewi \\ Jurusan Teknik Sipil dan Lingkungan, Institut Pertanian Bogor, \\ Kampus IPB Dramaga, Bogor, 16680. \\ *Penulis korespondensi. No Tel: 0251-8627225. Email: allen.kurniawan@gmail.com. \\ Diterima: 14 Juli 2014 \\ Disetujui: 25 Desember 2014
}

\begin{abstract}
Abstrak
Sistem penyaluran air limbah merupakan bagian penting dalam sistem prasarana perkotaan. Tujuan penelitian ini merancang konfigurasi sistem penyaluran air limbah domestik dan memodifikasi sistem drainase skala mikro di Kota Bogor untuk memenuhi debit penggelontoran. Data penelitian berupa data sekunder dari instansi terkait, studi pustaka, dan hasil beberapa penelitian terdahulu. Perkiraan jumlah penduduk setiap kelurahan pada tahun perencanaan 2035 menggunakan metode geometrik. Instalasi Pengolahan Air Limbah (IPAL) dibangun pada dua lokasi yaitu IPAL 1 di Kelurahan Bantarjati dan IPAL 2 di Kelurahan Mekarwangi. Perencanaan blok pelayanan sebanyak 254 buah dan jumlah manhole sebanyak 334 buah. Perhitungan kebutuhan air bersih menghasilkan nilai debit jam puncak air limbah (Qjp) rata-rata sebesar 5,75 L/detik. Debit air bersih menghasilkan perkiraan sebesar 80\% air limbah. Nilai Qp pada inlet IPAL 1 sebesar $0,59 \mathrm{~m}^{3} /$ detik dengan diameter $900 \mathrm{~mm}$, sedangkan nilai Qp pada inlet IPAL 2 sebesar 1,42 $\mathrm{m}^{3} /$ detik dengan diameter $1000 \mathrm{~mm}$. Pengaliran air limbah diusahakan secara gravitasi dengan kedalaman galian maksimum sebesar $6 \mathrm{~m}$. Sistem drainase skala mikro dirancang untuk memenuhi debit penggelontoran. Perhitungan intensitas hujan terpilih menggunakan Metode Sherman dengan Periode Ulang Hujan (PUH) untuk 20 tahun. Titik penggelontoran sebanyak 53 titik dengan debit penggelontoran rata-rata sebesar $0,03 \mathrm{~m}^{3} /$ detik. Debit saluran drainase rata-rata sebesar $0,25 \mathrm{~m}^{3} /$ detik. Saluran drainase skala mikro berbentuk persegi panjang dengan lebar dan tinggi ratarata sebesar $0,43 \mathrm{~m}$ dan $0,42 \mathrm{~m}$.
\end{abstract}

Kata kunci: air limbah domestik, debit penggelontoran, drainase skala mikro, pengolahan limbah, prasarana kota.

\begin{abstract}
Sewerage system is an important part of the urban infrastructure. The research objectives were to design a system configuration domestic wastewater sewerage and modify drainage systems in Bogor City for flushing discharge. The research used secondary data from relevant institutions, literature, and the results of previous researches. Estimated of the population of each village in 2035 used geometric method. Wastewater Treatment Plant (WWTP) would be constructed in two locations in Bantarjati and Mekarwangi Village. Planning of services area included 254 blocks and the number of manholes were 334. Clean water which produced peak hours flowrate (Qph) was $5.75 \mathrm{~L} / \mathrm{sec}$. Water flowrate produced an estimated of $80 \%$ wastewater flowrate. Q peak at the inlet of the WWTP 1 was $0.59 \mathrm{~m}^{3} / \mathrm{sec}$ with diameter of $900 \mathrm{~mm}$, while Q peak at the inlet of the WWTP 2 was $1.42 \mathrm{~m}^{3} / \mathrm{sec}$ with diameter of $1000 \mathrm{~mm}$. The stream of wastewater carried out by gravity with the maximum digging depth of $6 \mathrm{~m}$. The system of micro-scale drainage was designed to supply flushing flowrate. Rainfall intensity calculation is done using the Sherman Method with period of 20 years rain repetition. Flushing points were 53 with flowrate average of $0.03 \mathrm{~m}^{3} / \mathrm{sec}$. Drainage flowrate average was $0.25 \mathrm{~m}^{3} / \mathrm{sec}$. Micro-scale drainage was designed rectangular. Result of the width and height average dimension were $0.43 \mathrm{~m}$ and $0.42 \mathrm{~m}$, respectively.
\end{abstract}

Keywords: domestic wastewater sewerage, flushing flowrate, micro-scale drainage, urban infrastructure, wastewater treatment.

\section{PENDAHULUAN}

Penggunaan air minum menghasilkan sekitar $80 \%$ air limbah. Konsentrasi air limbah di atas baku mutu regulasi dan tanpa penanganan akan mencemari lingkungan sehingga harus dikumpulkan dan dialirkan menuju Instalasi Pengolahan Air Limbah (IPAL). Di Indonesia, sistem pengolahan air limbah melayani sebagian kecil penduduk karena biaya konstruksi dan pengolahan mahal. Sistem pengolahan hampir sebagian besar bersifat individu, berupa tangki septik. Unit tersebut tidak layak dibangun pada wilayah dengan tingkat kepadatan penduduk tinggi karena air limpasan tangki septik dapat mencemari ketersediaan air tanah.

Tingkat pencemaran air menjadi masalah utama bagi kota-kota besar di Pulau Jawa, seperti 
Kota Bogor. Kandungan bakteri Escherichia coli pada dua sungai utama di Kota Bogor, yaitu Sungai Ciliwung dan Sungai Cisadane, sangat tinggi. Menurut data Badan Lingkungan Hidup (BLH) Kota Bogor tahun 2012 (Anonim, 2012), kadar E. coli di Sungai Ciliwung bagian hulu hingga hilir berkisar 40.000-120.000 sel/100 mL, sedangkan Sungai Cisadane bagian hulu hingga hilir berkisar 18.000-90.000 sel/100 mL. Baku mutu Keputusan Menteri Negara Lingkungan Hidup Nomor 112 tahun 2003 tentang Baku Mutu Air Limbah Domestik sebesar $5.000 \mathrm{sel} / 100 \mathrm{~mL}$ sehingga air sungai termasuk dalam kategori tercemar parah. Dengan demikian, IPAL limbah domestik menjadi solusi terbaik sehingga air limbah tidak langsung terakumulasi di dalam lingkungan. Tidak hanya ketersediaan IPAL dibutuhkan, tetapi perencanaan sistem penyaluran air limbah dari sumber penghasil air limbah domestik menuju tempat pengolahan sangat diperlukan sehingga pengaliran dan pengolahan terintegrasi di dalam ruang lingkup pengelolaan air limbah secara berkesinambungan.

Penggelontoran merupakan penambahan air dengan debit dan kecepatan tertentu ke dalam saluran. Penggelontoran bertujuan untuk membuat aliran dalam pipa berjalan lancar sehingga sedimen dan kepekatan air limbah dapat dikurangi atau dihilangkan (Gambiro, 2012). Air penggelontoran tidak boleh mengotori saluran (Ilmi, 2009). Air penggelontor dapat berasal dari air tanah, air hujan, air minum dari Perusahaan Daerah Air Minum (PDAM), air sungai, danau, dan sebagainya. Drainase skala mikro dapat dirancang untuk memenuhi debit penggelontoran dalam sistem penyaluran air limbah. Cara seperti ini menghemat penggunaan air minum PDAM melalui pemanfaatan air limpasan sehingga mempunyai nilai daya guna di lingkungan.

Berdasarkan penjabaran masalah tersebut, penelitian ini bertujuan untuk merancang konfigurasi sistem penyaluran air limbah domestik menuju IPAL dan memodifikasi konfigurasi sistem drainase skala mikro menuju bangunan penggelontoran di Kota Bogor. Penelitian ini dapat dimanfaatkan sebagai usulan dan rekomendasi teknis dalam mempermudah pengelolaan limbah cair Kota Bogor.

\section{METODE PENELITIAN}

Penelitian ini mengambil lokasi perencanaan di wilayah administratif Kota Bogor dan dilaksanakan pada bulan Maret hingga Mei 2014. Pengambilan data jumlah penduduk dilaksanakan pada seluruh kelurahan di setiap kecamatan di Kota Bogor dan data curah hujan diperoleh dari stasiun klimatologi Kota Bogor. Bahan penelitian menggunakan data sekunder berupa luas wilayah dan jumlah penduduk setiap kelurahan di Kota Bogor, serta berbagai jenis peta. Kriteria peta dalam penelitian ini adalah peta topografi, peta kontur, peta kontur ketinggian, peta kepadatan penduduk, peta curah hujan, peta administrasi, dan data curah hujan Kota Bogor. Alat pendukung penelitian menggunakan seperangkat laptop yang dilengkapi perangkat lunak Microsoft Excel, Arc Map, dan Google Earth.

Perhitungan proyeksi penduduk tahun 2035 menggunakan tiga metode, yaitu metode aritmatik, metode geometrik, dan metode eksponensial. Metode terpilih berdasarkan nilai simpangan terkecil. Tahapan dan prosedur analisis untuk sistem penyaluran air limbah dan drainase skala mikro disajikan pada Lampiran 1, sedangkan persamaan rancangan sistem disajikan pada Lampiran 2.

\section{HASIL DAN PEMBAHASAN}

\section{Proyeksi Jumlah Penduduk}

Pada perencanaan sistem penyaluran air limbah, perkembangan penduduk di masa depan hingga akhir periode perencanaan perlu diketahui. Jumlah penduduk sangat mempengaruhi debit air limbah. Apabila jumlah penduduk meningkat, maka penanganan air limbah akan semakin besar. Perkiraan jumlah penduduk menggunakan data kependudukan tahun 2008-2012 sehingga prediksi jumlah penduduk tahun 2035 dapat ditentukan. Proyeksi jumlah penduduk menggunakan metode aritmatika, metode geometrik, dan metode eksponensial. Pemilihan metode berdasarkan hasil nilai simpangan terkecil. Nilai simpangan didapatkan dari selisih jumlah penduduk hasil sensus dengan jumlah penduduk hasil proyeksi. Sebenarnya, nilai simpangan pada metode geometrik dan eksponensial memiliki nilai ekuivalen di setiap kelurahan. Namun, metode geometrik memiliki nilai laju pertumbuhan $(r)$ lebih besar, yaitu $1,96 \%$, dibandingkan dengan nilai $r$ pada metode eksponensial, yaitu $1,94 \%$. Penentuan periode perencanaan berdasarkan nilai $r$ tertinggi (Imhoff dan Fair, 1956) sehingga metode terpilih adalah geometrik.

Sistem penyaluran air limbah ini dirancang untuk tahun perencanaan 2035. Hasil perhitungan proyeksi Kota Bogor menggunakan metode geometrik disajikan dalam Gambar 1. Berdasarkan Gambar 1, pertumbuhan penduduk Kota Bogor meningkat setiap tahun proyeksi. Laju pertumbuhan penduduk Kota Bogor sebesar 2,83\% setiap tahun. Jumlah penduduk tahun 2014 sebanyak 1.044.270 


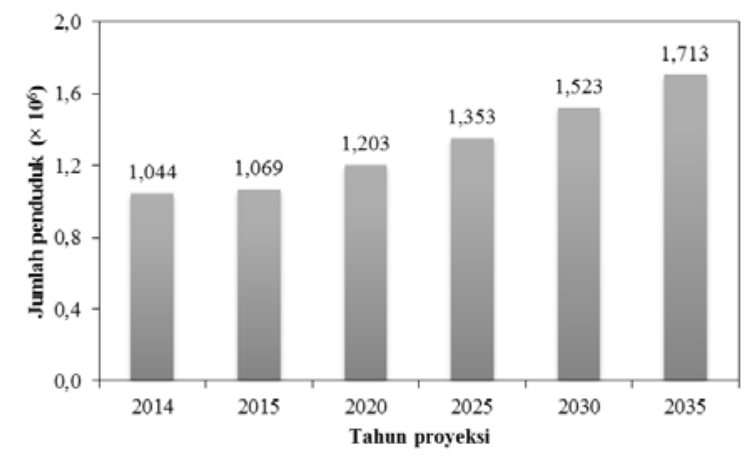

Gambar 1. Hasil proyeksi penduduk Kota Bogor.

jiwa dan meningkat sebanyak 1.712 .887 jiwa pada tahun 2035. Proyeksi jumlah penduduk setiap kelurahan menghasilkan jumlah penduduk tertinggi sebanyak 134.964 jiwa pada tahun 2035 di Kelurahan Kencana, sedangkan jumlah penduduk terendah sebanyak 1768 jiwa di Kelurahan Pabaton.

\section{Perhitungan kebutuhan air}

Perhitungan kebutuhan air Kota Bogor berdasarkan hasil perhitungan kebutuhan air dari Perusahaan Daerah Air Minum Tirta Pakuan Kota Bogor tahun 2013-2015. Persentase pelayanan meningkat setiap tahun. Pada tahun 2035, persentase pelayanan diperkirakan mencapai $95 \%$. Sebagian besar air limbah dihasilkan dari sisa penggunaan air bersih sehingga konsumsi air bersih harus diketahui berdasarkan standar pelayanan berdasarkan jenis kota. Standar tersebut dikeluarkan oleh Ditjen Cipta Karya Departemen Pekerjaan Umum (DPU).

Berdasarkan Tabel 1, Kota Bogor termasuk ke dalam kategori kota metropolitan dengan jumlah penduduk lebih dari satu juta jiwa sehingga kebutuhan air bersih sebesar 190 L/jiwa/hari. Kebutuhan domestik dihitung sesuai dengan jumlah penduduk terlayani dan konsumsi air minum, sedangkan kebutuhan non domestik diperkirakan sekitar 30\%. Nilai kebutuhan non domestik sekitar $25 \%$ dari kebutuhan domestik dengan pertambahan setiap tahun sekitar $2 \%$ sehingga nilai kebutuhan non domestik diperkirakan sebesar 30\%. PDAM Tirta Pakuan Kota Bogor merencanakan kehilangan air setiap tahun berkurang sebesar 1\% sehingga kehilangan air pada tahun 2035 sekitar 12\%.

Faktor harian maksimum berdasarkan Ditjen Cipta Karya DPU sebesar 1,1 dan faktor jam puncak sebesar 1,5. Nilai faktor jam puncak dan faktor harian maksimum dapat berbeda pada setiap daerah. Hal ini disebabkan perbedaan jumlah kepadatan penduduk dan jenis aktivitas pada setiap daerah pelayanan (Bose dkk., 2012). Perhitungan faktor harian maksimum dan faktor jam puncak perlu memperhatikan penggunaan air pada jam
Tabel 1. Pembagian kota berdasarkan jumlah penduduk.

\begin{tabular}{clcc}
\hline Kategori & Jenis kota & $\begin{array}{c}\text { Jumlah } \\
\text { penduduk }\end{array}$ & $\begin{array}{c}\text { Kebutuhan } \\
\text { air bersih } \\
\text { (L/jiwa/hari) }\end{array}$ \\
\hline I & Metropolitan & $>1.000 .000$ & 190 \\
II & Kota besar & $\begin{array}{c}500.000- \\
1.000 .000\end{array}$ & 170 \\
& Kota sedang & $\begin{array}{c}100.000- \\
500.000\end{array}$ & 130 \\
II & Kota kecil & $20.000-$ & 100 \\
IV & & 100.000 & \\
& Desa & $<20.000$ & 80 \\
V & & & \\
\hline
\end{tabular}

puncak (penggunaan air tertinggi), faktor jam puncak dan faktor harian maksimum setempat melalui pembagian penggunaan air per jam dalam satu hari. Menurut Imam dan Elnakar (2014), faktor jam puncak diperoleh melalui perbandingan debit jam puncak dan debit rata-rata harian dalam satu minggu, sedangkan faktor harian maksimum diperoleh melalui perbandingan debit maksimum hari dalam satu minggu dan debit rata-rata harian dalam seminggu.

Perhitungan debit air limbah menggunakan nilai debit air minum pada jam puncak $\left(Q_{j p}\right)$. Nilai $Q_{j p}$ rata-rata pada setiap segmen pipa untuk seluruh blok pelayanan adalah $0,004 \mathrm{~m}^{3} /$ detik. Nilai $Q_{j p}$ terbesar pada blok 1 (Kelurahan Mekarwangi dan Kelurahan Kencana) sebesar $0,12 \mathrm{~m}^{3} /$ detik, sedangkan nilai $Q_{j p}$ terkecil pada blok 154 (Kelurahan Cikaret dan Kelurahan Mulyaharja) sebesar $3 \times 10^{-5} \mathrm{~m}^{3} /$ detik.

\section{Sistem penyaluran air limbah}

Perhitungan sistem penyaluran air limbah domestik diawali dengan membuat blok-blok pelayanan pada peta Kota Bogor. Jumlah blok pelayanan sebanyak 254 blok. Batas blok pelayanan adalah jalan dan sungai. Gambar blok pelayanan serta sistem perpipaan disajikan pada Lampiran 3. Blok pelayanan dengan kepadatan penduduk tertinggi sebesar 25.309 jiwa $/ \mathrm{km}^{2}$ terdapat di Kelurahan Panaragan dan Paledang. Blok pelayanan dengan kepadatan penduduk terendah sebesar 146 jiwa $/ \mathrm{km}^{2}$ terdapat di Kelurahan Sindang Barang dan Bubulak. Perhitungan luas setiap blok pelayanan menggunakan perangkat lunak ArcMap.

Sistem perpipaan dibuat mengikuti jalan dan sistem pengaliran diusahakan secara gravitasi sehingga perencanaan jaringan perpipaan harus memperhatikan kontur. Penyaluran air limbah diusahakan melalui jalur dan waktu alir sesingkat mungkin untuk menghindari pencemaran lingkungan (Widiana dkk., 2012). Jumlah segmen pipa sebanyak 323 segmen. Segmen dibatasi oleh 
lubang pemeriksaan (manhole) dengan jarak sebesar $210 \mathrm{~m}$. Manhole merupakan lubang pada jalur pipa air limbah untuk mempermudah petugas melakukan pemeriksaan, perbaikan, maupun pembersihan saluran dari kotoran-kotoran yang menghambat jalur pengaliran (Rahmawati dkk., 2013). Manhole direncanakan sebanyak 334 buah. Manhole diletakan pada perubahan kemiringan saluran, perubahan arah aliran, dan perubahan diameter saluran (Howard, 2009).

Kota Bogor merupakan kota dengan luas area cukup besar dan kepadatan penduduk tinggi sehingga dua unit IPAL diperlukan untuk menampung debit air limbah seluruh penduduk kota. Lokasi IPAL 1 berada di Kelurahan Bantarjati dan IPAL 2 berada di Kelurahan Mekarwangi. Selain kondisi topografi daerah pelayanan, penentuan lokasi IPAL juga mempertimbangkan faktor lain, antara lain lokasi berupa tanah kosong, lokasi jauh dari permukiman, lokasi terletak dekat dengan badan air penerima (Sungai Ciliwung dan Sungai Kaliangke), ketersediaan luas lahan cukup memadai, serta pengaliran diusahakan secara gravitasi menuju dataran topografi terendah (Ginanjar, 2008). Rencana lokasi IPAL dapat disajikan pada Gambar 2.

Perhitungan dimensi pipa dapat diketahui jika jumlah populasi dan jumlah pemakaian air bersih telah diketahui. Perhitungan dimensi pipa didasarkan pada Populasi Ekuivalen (PE). Nilai PE berbeda-beda sesuai dengan jenis kegiatan. Air limbah domestik berasal dari limbah rumah tangga sehingga nilai $\mathrm{PE}$ terpilih adalah rumah biasa dan rumah mewah. Berdasarkan klasifikasi nilai $\mathrm{PE}$ Ditjen Cipta Karya DPU, nilai PE dari kedua jenis rumah tangga tersebut adalah 1 dan 1,67. Nilai tersebut menghasilkan nilai $\mathrm{PE}$ rata-rata sebesar 1,33 .

Jumlah jalur pipa menuju IPAL 1 adalah dua jalur. Jalur terpanjang menuju IPAL 1 yaitu jalur pertama dengan panjang pipa $8280 \mathrm{~m}$, sedangkan jalur kedua memiliki panjang $7680 \mathrm{~m}$. Titik awal jalur pertama terdapat di Kelurahan Katulampa. Perhitungan debit puncak ( $Q$ peak) air limbah merupakan akumulasi dari setiap segmen pipa hingga masuk IPAL. Nilai total $Q$ peak pada jalur pertama sebesar $0,39 \mathrm{~m}^{3} /$ detik. Titik awal jalur kedua terdapat di Kelurahan Cikaret. Nilai total $Q$ peak pada jalur kedua sebesar $0,27 \mathrm{~m}^{3} /$ detik sehingga nilai $Q$ peak pada inlet IPAL 1 sebesar $0,59 \mathrm{~m}^{3} /$ detik.

Jumlah jalur pipa menuju IPAL 2 adalah dua jalur. Jalur terpanjang menuju IPAL 2 yaitu jalur kedua dengan panjang pipa $12.240 \mathrm{~m}$, sedangkan jalur pertama memiliki panjang $9780 \mathrm{~m}$. Titik awal jalur pertama terdapat di Kelurahan Loji. Nilai total

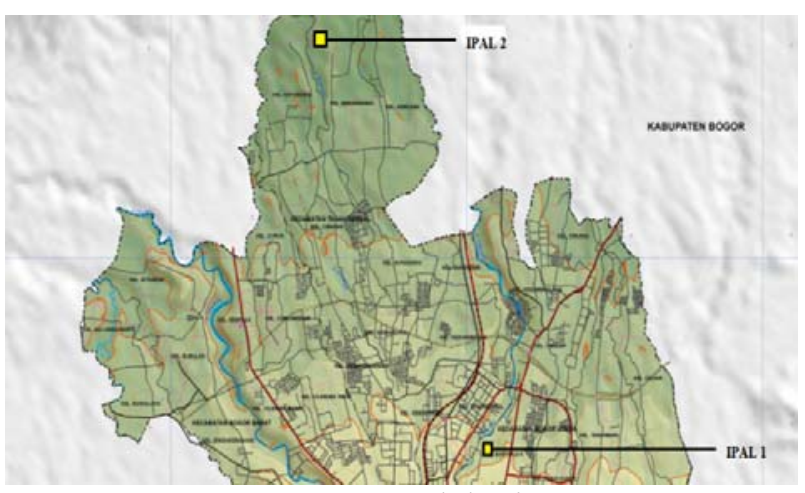

Gambar 2. Rencana lokasi IPAL.

$Q$ peak pada jalur pertama sebesar $0,27 \mathrm{~m}^{3} /$ detik. Titik awal jalur kedua terdapat di Kelurahan Tegal Gundil. Nilai total $Q$ peak pada jalur kedua sebesar $1,16 \mathrm{~m}^{3} /$ detik sehingga nilai $Q$ peak pada inlet IPAL 2 sebesar $1,42 \mathrm{~m}^{3} /$ detik. Nilai debit infiltrasi ( $Q$ infiltrasi) saluran sama pada setiap segmen pipa sebesar $0,0004 \mathrm{~m}^{3} /$ detik. Hal ini disebabkan $Q$ infiltrasi saluran tergantung dari panjang segmen pipa sebesar $210 \mathrm{~m}$. Debit infiltrasi berasal dari penambahan limpasan air hujan melalui lubang manhole dan tutup-tutup bak kontrol (debit inflow). Nilai debit minimum ( $Q$ min) bervariasi sesuai dengan jumlah penduduknya. Nilai $Q$ min digunakan dalam menentukan kedalaman minimum untuk menentukan kelayakan penggelontoran (Watson, 2010).

Perhitungan dimensi pipa berdasarkan nilai rasio tinggi muka air dan diameter pipa $(d / D)$. Nilai rasio $d / D$ diperlukan karena penyaluran air limbah tidak memerlukan tekanan yang menyebabkan saluran penuh. Nilai rasio $d / D$ terpilih sebesar 0,8 sehingga nilai $Q$ peak/Q full didapatkan dari grafik design of main sewers (Qasim, 1999) sebesar 0,98.

Nilai kecepatan aliran awal ( $v$ full awal) diasumsikan sebesar $1 \mathrm{~m} /$ detik. Namun, tidak semua segmen pipa memiliki $v$ full awal sebesar 1 m/detik. Pada segmen pipa 11-10 di Kelurahan Katulampa, nilai $v$ full awal diasumsikan sebesar $2,5 \mathrm{~m} /$ detik. Nilai $v$ full asumsi ini disesuaikan dengan nilai diameter hitung ( $D$ hitung) yang diinginkan. Nilai $D$ hitung berbanding terbalik dengan nilai $v$ full asumsi sehingga nilai $v$ full asumsi akan semakin besar jika nilai $D$ hitung semakin kecil, begitu pula sebaliknya. Nilai $v$ full rencana berkisar $2 \mathrm{~m} /$ detik. Perubahan diamater pipa antar segmen dibuat tidak terlalu signifikan. Perubahan diameter ini disesuaikan dengan diameter increaser di pasaran. Perubahan minimal diameter pipa sebesar $50 \mathrm{~mm}$ dan maksimal 100 $\mathrm{mm}$. Diameter pipa inlet pada IPAL 1 sebesar 900 $\mathrm{mm}$, sedangkan diameter pipa inlet pada IPAL 2 sebesar $1000 \mathrm{~mm}$. Nilai kemiringan pipa (s) diasumsikan dengan syarat nilai $Q$ full akhir lebih 
besar sama dengan $Q$ full awal dan nilai $v$ full akhir 0,6-3 m/detik. Nilai $s$ diusahakan sekecil mungkin, tetapi mampu memberikan kecepatan yang diinginkan sehingga tidak merusak permukaan saluran (Thomas, 2010).

Perhitungan volume air limbah memerlukan nilai rasio antara ketinggian air dengan diameter pipa ( $\mathrm{d} \mathrm{min} / \mathrm{D}$ full) dan rasio kecepatan minimum dengan kecepatan maksimum ( $v$ min/v full). Nilai kedua variabel tersebut didapatkan dari grafik design of main sewers. Nilai $d \mathrm{~min} / \mathrm{D}$ full tergantung pada nilai rasio debit minimum dengan debit maksimum ( $Q \mathrm{~min} / \mathrm{Q}$ full). Pada segmen pipa 1-3 (Lampiran 3) di Kelurahan Katulampa, nilai $Q$ $\mathrm{min} / \mathrm{Q}$ full sebesar 0,004 sehingga nilai $d \mathrm{~min} / \mathrm{D}$ full sebesar 0,008. Kemudian, nilai $v \mathrm{~min} / v$ full tergantung pada nilai $d \mathrm{~min} / \mathrm{D}$ full. Jadi, nilai $v$ $\mathrm{min} / v$ full sebesar 0,31 untuk $d \mathrm{~min} / \mathrm{D}$ full sebesar 0,008 .

Penggelontoran merupakan penambahan air dengan debit dan kecepatan tertentu ke dalam saluran. Penggelontoran membuat aliran dalam pipa berjalan lancar untuk menghilangkan sedimen dan mengurangi kepekatan air limbah (Gambiro, 2012). Penggelontoran dilakukan jika nilai ketinggian air minimum (d min) kurang dari $100 \mathrm{~mm}$ dan kecepatan minimum ( $v$ min) kurang dari 0,6 $\mathrm{m} /$ detik. Tidak semua segmen pipa mengalami penggelontoran, misalnya segmen pipa $84-85$ (Lampiran 3) di Kelurahan Tegalega. Nilai $d$ min pada segmen ini telah mencapai 106,18 mm dengan $v$ min sebesar $1,73 \mathrm{~m} /$ detik sehingga penggelontoran tidak perlu dilakukan. Jika segmen pipa mengalami penggelontoran, maka perhitungan debit penggelontoran perlu dilanjutkan. Kisaran debit gelontor $\left(Q_{g}\right)$ ke dalam setiap segmen pipa sebesar $0,03 \mathrm{~m}^{3} /$ detik dan kisaran volume gelontor $\left(V_{g}\right)$ sebesar $2,72 \mathrm{~m}^{3}$.

Perhitungan volume air limbah akhir dilakukan pada segmen pipa yang mengalami penggelontoran. Pada perhitungan volume air limbah akhir, $Q$ min awal akan ditambahkan dengan debit penggelontoran sehingga menghasilkan nilai $Q$ $\min / Q$ full baru. Pada segmen 1-3, nilai $Q$ min awal sebesar $1 \times 10^{-4} \mathrm{~m}^{3} /$ detik. Setelah ditambah dengan debit penggelontoran, nilai $Q$ min berubah menjadi $0,02 \mathrm{~m}^{3} /$ detik. Hal ini berdampak pada nilai $d \min$ dan $v$ min. Nilai $d$ min bertambah menjadi lebih dari $100 \mathrm{~mm}$. Pertambahan nilai $d$ min pada segmen 1-3 sebelum penggelontoran adalah 1,57 $\mathrm{mm}$ dan nilai $d$ min setelah penggelontoran bertambah menjadi $135,06 \mathrm{~mm}$. Nilai ini telah memenuhi persyaratan ketinggian dan kecepatan minimum di dalam pipa.

Pada tahap perhitungan penanaman pipa, dua kondisi mungkin terjadi, yaitu penggunaan pompa dan drop manhole. Pompa digunakan jika kedalaman galian terlalu dalam atau kemiringan pipa lebih besar dibandingkan kemiringan elevasi tanah. Drop manhole digunakan jika nilai kemiringan pipa lebih kecil dibandingkan dengan kemiringan tanah. Pada penelitian ini, pompa digunakan sebanyak 19 buah. Contoh penggunaan pompa terdapat pada segmen 3-4 di Kelurahan Tajur. Elevasi Dasar Saluran akhir (EDS (Ds)) pada segmen pertama harus sama dengan Elevasi Dasar Saluran awal (EDS (Us)) segmen selanjutnya. Elevasi Muka Air akhir (EMA (Ds)) pada segmen pertama pun harus sama dengan Elevasi Muka Air awal (EMA (Us)) segmen selanjutnya. Hal ini untuk mencegah terjadinya arus balik. Namun, nilai $E D S$ (Ds) segmen 1-3 tidak sama dengan EDS (Us) segmen 3-4. Hal ini disebabkan adanya perubahan diameter pipa segmen 1-3 menuju segmen 3-4. Selain perubahan diameter pipa, perbedaan ini juga terjadi jika terdapat drop manhole, pompa, atau pertemuan pipa pada persimpangan (Kerr, 2008).

Fungsi pompa adalah mengangkut air limbah dari tempat rendah ke tempat lebih tinggi untuk menghindari penanaman pipa yang terlalu dalam dan memberikan tekanan yang cukup untuk proses pengolahan. Kapasitas pompa direncanakan berdasarkan aliran puncak air limbah, demikian pula dengan perpipaan pada rumah pompa. Semakin besar kapasitas pompa, biaya untuk perawatan dan pengontrolan sistem perpompaan akan semakin mahal (Analisse, 2009). Pompa sentrifugal merupakan jenis pompa yang umum digunakan untuk memompa air limbah karena tidak mudah tersumbat. Penggunaan pompa rendam (submersible) untuk air limbah lebih baik karena dapat mencegah terjadinya kavitasi (Chapin, 2006).

\section{Penentuan Intensitas Curah Hujan}

Sistem perencanaan drainase skala mikro memerlukan data curah hujan tahunan dari 2000 hingga 2013. Langkah awal untuk pengolahan data curah hujan adalah perhitungan hujan rencana melalui Metode Gumbel. Metode ini sering digunakan untuk menganalisis keadaan maksimum seperti analisis frekuensi banjir (Okonkwo dan Mbajiorgo, 2010). Beberapa data dari sumber literatur dibutuhkan untuk kalkulasi Metode Gumbel, seperti nilai faktor reduced standar deviasi $\left(S_{n}\right)$, faktor reduced mean $\left(Y_{n}\right)$, dan reduced variate $\left(Y_{t}\right)$. Nilai $S_{n}$ dan $Y_{n}$ tergantung pada jumlah data curah hujan (n). Pada penelitian ini, curah hujan menggunakan 14 data sehingga nilai $S_{n}$ dan $Y_{n}$ berturut-turut adalah 0,01 dan 0,51 (Suripin, 2004). Nilai variabel $Y_{t}$ tergantung pada tahun Periode Ulang Hujan (PUH). Penelitian ini menggunakan PUH 5, 10, dan 20 sehingga nilai $Y_{t}$ 
diperoleh berturut-turut sebesar 1,49; 2,25; dan 2,96. Analisis frekuensi kejadian hujan menghasilkan nilai hujan rencana satu hari $\left(R_{24}\right)$ dalam perhitungan intensitas curah hujan. Nilai $R_{24}$ untuk masing-masing PUH adalah 361,427 mm; $394,254 \mathrm{~mm}$; dan 425,315 mm.

Perhitungan intensitas curah hujan dilakukan dengan menggunakan tiga metode, yaitu Metode Talbot, Metode Sherman, dan Metode Ishiguro. Pemilihan ketiga metode tersebut berdasarkan pada nilai standar deviasi $(S D)$ terkecil. Nilai $S D$ dari ketiga metode tersebut untuk PUH 20 berturut-turut sebesar 8,80; 5,64; dan 7,59. Berdasarkan hasil tersebut, metode terpilih adalah Metode Sherman. Standar deviasi adalah akar kuadrat dari varians dan menunjukan standar penyimpangan data terhadap nilai rata-rata. Semakin kecil nilai standar deviasi, maka implementasi semakin baik karena tingkat kesalahan semakin kecil (Wardhana, 2013). Kurva Intencity Duration Frequency (IDF) dibuat berdasarkan hasil perhitungan Metode Sherman. Kurva IDF disajikan pada Gambar 3.

Berdasarkan kurva pada Gambar 3, nilai PUH yang digunakan untuk perencanaan sistem drainase skala mikro adalah PUH 20. Intensitas hujan pada menit ke-59 untuk PUH 5, 10, dan 20 berturut-turut adalah 204,76 mm/jam; 221,95 mm/jam; dan $238,15 \mathrm{~mm} / \mathrm{jam}$. Nilai tersebut sesuai dengan pendapat Willems (2007). Semakin besar tahun PUH, semakin tinggi tingkat intensitas hujan. Hal ini akan berdampak pada rancangan sistem drainase. Jika intensitas hujan semakin besar, maka rancangan dimensi saluran akan semakin besar.

Kurva IDF adalah salah satu alat yang paling umum digunakan dalam rekayasa sumber daya air, baik untuk perencanaan, perancangan dan operasi proyek sumber daya air, atau perlindungan dari berbagai proyek rekayasa (misalnya jalan raya, dan lain-lain) (Taheri, 2011). Suroso (2006) menyebutkan bahwa analisis IDF memerlukan analisis frekuensi dengan menggunakan seri data dari rekaman data hujan.

\section{Perencanaan Sistem Drainase Skala Mikro}

Perhitungan sistem drainase skala mikro diawali dengan membuat blok-blok pelayanan di Kota Bogor. Blok pelayanan sistem drainase skala mikro dibatasi oleh jalan utama. Selain itu, blok pelayanan sistem drainase mikro harus dekat dengan bangunan penggelontoran karena air limpasan yang masuk ke dalam saluran drainase akan dialirkan langsung ke dalam bangunan penggelontoran. Selanjutnya, luasan area blok pelayanan juga harus diperhatikan. Hal ini disebabkan luasan blok pelayanan berbanding lurus dengan debit limpasan. Gambar blok pelayanan

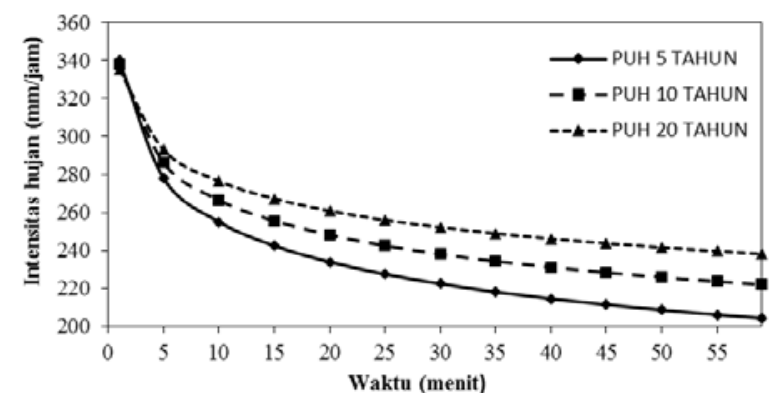

Gambar 3. Kurva IDF berdasarkan metode Sherman.

drainase skala mikro dapat dilihat pada Lampiran 4. Kebutuhan debit penggelontoran berkisar 0,03 $\mathrm{m}^{3} /$ detik sehingga blok pelayanan tidak memerlukan luasan terlalu besar.

Jumlah penggelontoran pada sistem penyaluran air limbah domestik menuju IPAL adalah 53 titik. Satu sistem drainase mikro minimal melayani tiga blok pelayanan dan maksimal melayani enam blok pelayanan. Pada perhitungan debit saluran, nilai koefisien pengaliran (C) permukiman adalah 0,4 . Nilai $C$ tergantung pada kondisi dan karakteristik daerah pengaliran. Nilai $C$ akan semakin besar jika daerah kedap air di daerah pengaliran bertambah besar (Yiping 2006).

Kisaran debit pada saluran drainase mikro adalah $0,25 \mathrm{~m}^{3} /$ detik. Pada perhitungan dimensi saluran, nilai lebar dasar saluran (b) diasumsikan sesuai dengan nilai $b$ hasil observasi di lapangan. Hasil observasi nilai $b$ pada saluran drainase jalan arteri sekitar 0,4-1 m sehingga nilai kisaran $b$ pada penelitian ini adalah $0,43 \mathrm{~m}$. Kecepatan aliran diasumsikan berada diantara 0,6-3 $\mathrm{m} /$ detik. Menurut Said (1992), kecepatan aliran kurang dari $0,6 \mathrm{~m} /$ detik menimbulkan sedimentasi dan menjadi tempat nyamuk bertelur, sedangkan kecepatan aliran lebih dari $3 \mathrm{~m} /$ detik menyebabkan erosi pada permukaan saluran. Jadi, kecepatan aliran diasumsikan sebesar $2 \mathrm{~m} /$ detik. Kedalaman saluran memiliki kisaran sebesar 0,42 m. Penentuan bentuk atau profil saluran perlu diperhatikan aspek ekonomi dengan luas penampang tertentu. Bentuk saluran direncanakan berupa saluran persegi. Saluran ini digunakan jika debit dihasilkan besar dan saluran merupakan saluran terbuka (Novak, 2010).

Variabel $x$ merupakan perbandingan antara lebar dengan kedalaman saluran. Nilai $x$ ini ditentukan berdasarkan ketetapan dari Departemen Pekerjaan Umum. Untuk kisaran debit air limpasan sebesar $0,25 \mathrm{~m}^{3} /$ detik, maka nilai $x$ adalah 1,00 . Kisaran debit akhir ( $Q$ cek) pada saluran drainase mikro adalah $0,61 \mathrm{~m}^{3} /$ detik. Nilai tersebut telah memenuhi debit penggelontoran yang diperlukan 
oleh sistem perencanaan air limbah dengan kisaran sebesar $0,03 \mathrm{~m}^{3} /$ detik. Debit air limpasan dari bangunan penggelontoran ke titik gelontor disalurkan dengan menggunakan pipa. Diameter pipa disesuaikan dengan kebutuhan debit penggelontoran sehingga diameter pipa yang masuk ke titik penggelontoran berbeda-beda. Diameter terbesar pada inlet titik gelontor sebesar $60 \mathrm{~mm}$, sedangkan diameter terkecil sebesar $5 \mathrm{~mm}$.

\section{Penentuan Kapasitas Bangunan Penggelontor}

Titik penggelontoran di seluruh Kota Bogor adalah 53 titik. Debit rata-rata influen bangunan penggelontor berkisar $0,25 \mathrm{~m}^{3} /$ detik, sedangkan debit rata-rata efluen bangunan penggelontor menuju sistem penyaluran air limbah berkisar 0,03 $\mathrm{m}^{3} /$ detik. Nilai debit influen bangunan penggelontor dihasilkan dari perhitungan debit limpasan air hujan pada sistem drainase mikro dan nilai debit efluen bangunan penggelontor dihasilkan dari perhitungan debit penggelontoran pada sistem penyaluran air limbah. Contoh bangunan penggelontor pertama pada segmen 1-3 di Kelurahan Katulampa. Debit influen bangunan penggelontoran sebesar 0,36 $\mathrm{m}^{3} /$ detik, sedangkan debit efluen sebesar 0,02 $\mathrm{m}^{3} /$ detik. Nilai debit influen memenuhi kapasitas yang diperlukan oleh titik gelontor bahkan berlebih. Kelebihan air ini akan ditampung di dalam bangunan penggelontoran (Calvin, 2009). Durasi untuk menampung air berlebih dalam bangunan penggelontoran berbeda-beda pada setiap segmen pipa yang digelontorkan. Kisaran penyimpanan air limpasan berlebih selama tujuh hari dalam bangunan penggelontoran.

Sistem penggelontoran dibagi menjadi dua, yaitu sistem kontinu dan sistem periodik (Anonim, 2011). Sistem kontinu adalah penggelontoran secara terus menerus dengan debit yang konstan. Kelebihan sistem kontinu tidak memerlukan bangunan penggelontor sepanjang jalur pipa, tetapi cukup berupa bangunan pada awal saluran atau berupa terminal clean out yang terhubung dengan pipa transmisi air penggelontor. Selain itu, kelebihan lain sistem kontinu adalah kemungkinan saluran tersumbat kecil, dapat terjadi pengenceran air limbah, serta sistem operasi mudah. Kekurangan sistem ini yaitu, debit penggelontoran konstan memerlukan dimensi saluran lebih besar, dan penambahan beban hidrolis terjadi pada IPAL.

Penggelontoran dengan sistem periodik dilakukan secara berkala pada kondisi aliran minimum. Kelebihan sistem ini adalah penggelontoran dilakukan minimal sekali dalam sehari dan penggelontoran dapat diatur sesuai kebutuhan. Kekurangan sistem ini adalah dimensi saluran relatif tidak besar karena debit gelontor tidak diperhitungkan, penggunaan sistem penggelontoran secara periodik menyebabkan unit bangunan penggelontor lebih banyak disepanjang saluran. Selain itu, saluran kemungkinan dapat tersumbat oleh kotoran.

\section{KESIMPULAN}

Rancangan sistem penyaluran air limbah domestik Kota Bogor diperoleh melalui empat tahap kalkulasi, yaitu perhitungan debit air limbah, dimensi saluran, volume air limbah, dan penanaman pipa. Konfigurasi sistem penyaluran air limbah domestik menuju dua lokasi IPAL ditentukan berdasarkan jumlah blok pelayanan, segmen pipa, dan manhole sebagai lubang pemeriksa. Satu segmen pipa melayani satu hingga tiga blok pelayanan. Diameter pipa pada inlet IPAL tidak melebihi $1000 \mathrm{~mm}$ dengan kisaran kecepatan aliran 0,6-3 $\mathrm{m} /$ detik. Penyaluran air limbah membutuhkan penggelontoran dari beberapa titik karena kedalaman dan kecepatan aliran tidak terpenuhi. Sumber kebutuhan air penggelontor berasal dari air hujan dalam rancangan sistem drainase skala mikro. Saluran drainase dirancang dalam bentuk persegi dengan debit aliran cukup sebagai pemasok penggelontoran air limbah.

\section{DAFTAR PUSTAKA}

Analisse, 2009. Cost of Sewage Pumping System. International Journal of Engine Technology, 243:265-272.

Anonim, 2005. Kriteria Perencanaan Sektor Air Bersih. Direktorat Jenderal Cipta Karya, Departemen Pekerjaan Umum, Jakarta.

Anonim, 2011. Tata Cara Rancangan Sistem Jaringan Perpipaan Air Limbah Terpusat tentang Pedoman Perencanaan. Direktorat Jenderal Cipta Karya, Departemen Pekerjaan Umum, Jakarta.

Anonim, 2012. Pencemaran Lingkungan Kota Bogor Tahun 2012. Badan Lingkungan Hidup Kota Bogor, Bogor.

Bose, A.R.J.C., Neelakantan, T.R., dan Mariappan, P., 2012. Peak Factor In The Design of Water Distribution-An Analysis. International Journal of Civil Engineering and Technology, 3(2):123-129.

Calvin, K., 2009. Flushing Periode of Sewer System. Journal of Enviromental Engineering, 234(9):124-132.

Chapin, J., 2006. Municipal Wastewater Pump Station Design Problems and Solutions. Proceedings of the Water Environment Federation, 2158-2164. 
Gambiro, H., 2012. Pengelolaan Limbah Cair Volume VI. Universitas Mercu Buana, Jakarta.

Ginanjar, Y., 2007. Alternatif Sistem Penyaluran Air Buangan Domestik Kecamatan Garut Kota dengan Sistem "Pipa Riol Kecil". Skripsi, Program Studi Teknik Lingkungan, Fakultas Teknik Sipil dan Lingkungan ITB, Bandung.

Howard, G., 2009. Design of Manhole Placement. Journal of Civil Engineering, 342:153-162.

Ilmi, N., 2009. Perencanaan Debit Penggelontoran Dalam Sistem Air Limbah. Jurnal Teknik Sipil, 211(2):243-250.

Imam, E.H., dan Elnakar, H.Y., 2014. Design Flow Factors for Sewerage Systems in Small Arid Communities. Journal of Advanced Research, 5(5):537-542.

Imhoff, K., dan Fair, G.M., 1956. Sewage Treatment. John Wiley \& Sons, Inc., New York.

Kerr, J., 2008. Hinton Eco-industrial Park First to Use Sewer System. International Journal of Environment Engineering and Technology, 101:4299.

Novak, P., 2010. Sediment Transport in Smooth Fixed Bed Channels. Journal Hydraulogic Civil Engineering, 101(9):1139-1154.

Okonkwo, G.I., dan Mbajiorgo, C.C., 2010. Rainfall Intensity Method Analysis for South Eastern Nigeria. International Journal of Agricultural Engineering: The CIGR eJournal, 12:1-15.

Qasim, S.R., 1998. Wastewater Treatment Plants. CRC Press, Boca Raton.

Taheri, B., 2011. Establishment of IntensityDuration-Frequency Curves for Precipitation. Journal of Hydrology, 347:197- 210.

Rahmawati, F., Oktiawan, W., dan Nugraha, W.D., 2013. Detail Engineering Design (DED) Sistem Penyaluran Air Limbah dan Instalasi
Pengolahan Air Limbah Kawasan Industri BSB City, Mijen Kota Semarang. Jurnal Lingkungan, 2(2):1-10 .

Said, M.E., 1992. Probabilistic Design of Open Drainage Channels. Journal Irrigation Drainage Engineering, 118(6):868-881.

Suripin, 2004. Sistem Drainase Perkotaan yang Berkelanjutan. Penerbit Andi, Yogyakarta.

Suroso, 2006. Analisis Curah Hujan Untuk Membuat Kurva Intensity-Duration-Frequency (IDF) di Kawasan Rawan Banjir Kabupaten Banyumas. Jurnal Teknik Sipil, 3(1):37-40.

Thomas, L., 2010. Planning of Hydrolic Piping System. Journal of Civil Engineering, 37:165173.

Wardhana, A.O., 2013. Perancangan Instrumentasi untuk Perhitungan Standar Deviasi dan Standar Error Barometer Tabung Bourdon. Skripsi, Program Studi Teknik Mesin, Universitas Dipenegoro, Semarang.

Watson, J., 2010. Calculation of Wastewater Discharge on Urban Sewer. Journal of Civil Engineering, 231(3):342-352.

Widiana, S., Wardana, I.W., dan Handayani, D.S., 2013. Perencanaan Teknis Sistem Penyaluran dan Pengolahan Air Buangan Domestik (Studi Kasus: Kelurahan Bojongsalaman Kecamatan Semarang Barat Kota Semarang). Jurnal Teknik Lingkungan, 2(1):1-9.

Willems, P., 2007. Compound Intensity Duration Frequency Relationships of Extreme Precipitation for Two Seasons and Two Storm Types. Journal of Hydrology, 233:189-205.

Yiping, G., 2006. Updating Rainfall IDF Relationships to Maintain Urban Drainage Design Standards. Journal of Hydrologic Engineering, 11:506-509. 
Lampiran 1. Diagram alir penelitian.

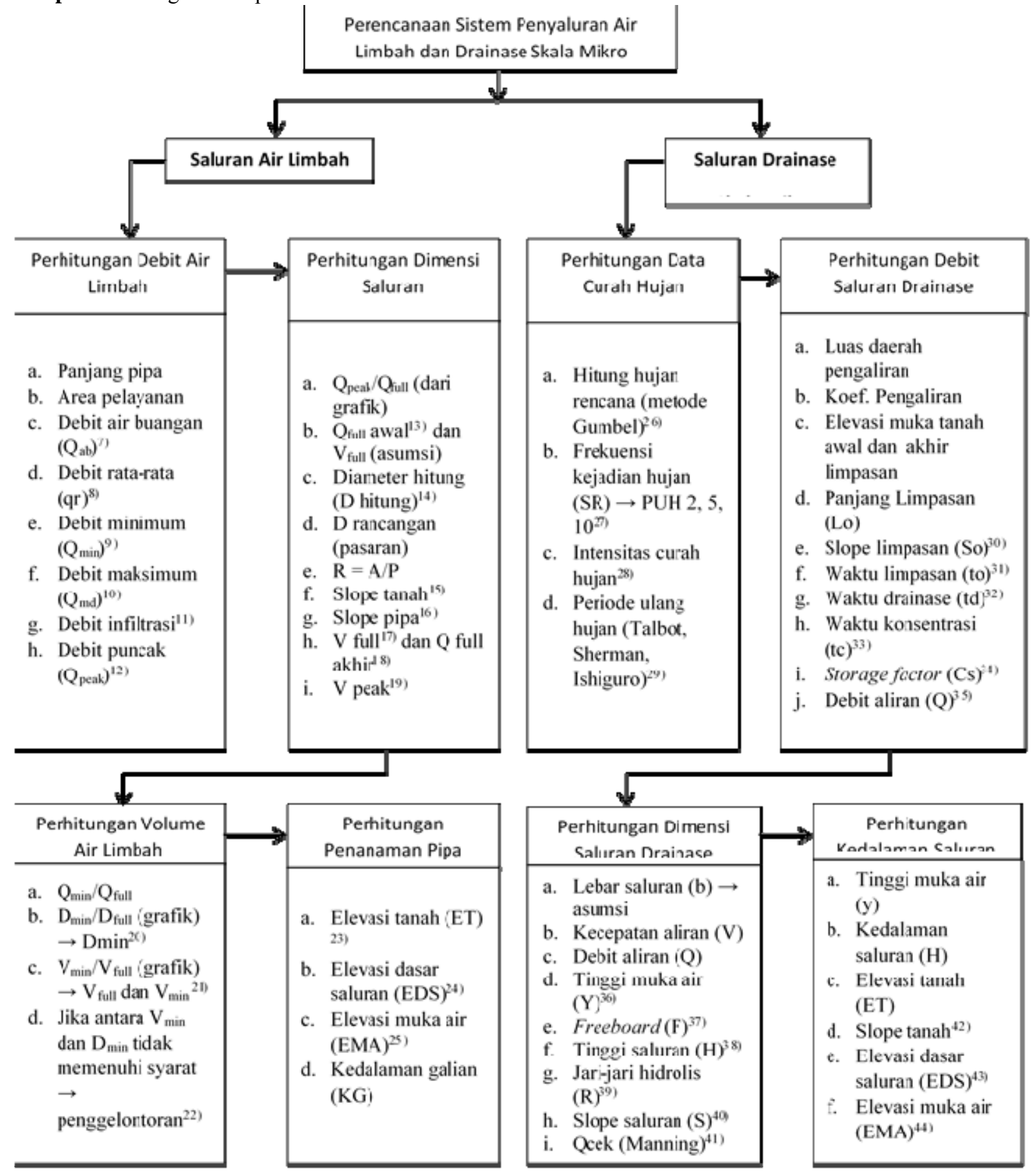


Lampiran 2. Rumus perhitungan sistem penyaluran air limbah dan drainase skala mikro.

No.

Pers.

Keterangan

Sistem Penyaluran Air Limbah

1) Aritmatika $\mathrm{Pn}=\mathrm{Po}+\mathrm{r}(\mathrm{Tn}-\mathrm{To})$

$\mathrm{r}=\frac{\mathrm{P}_{2}-\mathrm{P}_{1}}{\mathrm{~T}_{2}-\mathrm{T}_{1}}$

Geometri $P n=P o(1+r)^{n}$

$$
\mathrm{r}=\left(\frac{\mathrm{Pn}}{\mathrm{Po}_{\mathrm{o}}}\right)^{1 / \mathrm{n}}-1
$$

Eksponensial $\mathrm{Pn}=\mathrm{Po} e^{\mathrm{rn}}$

$\mathrm{r}=\frac{\ln \mathrm{Pn}-\ln \mathrm{Po}}{\mathrm{n}}$

2)

3)

4)

5)

6)

7)

17) Rumus-rumus penggelontoran :

$$
\begin{aligned}
& \text { slope tanah } \\
& =\frac{(\text { elevasi tanah manhole } 1)-((\text { elevasi tanah manhole } 2)}{\text { panjang pipa }}
\end{aligned}
$$

Slope pipa merupakan asumsi dengan syarat yang harus dipenuhi : $\mathrm{Q}$ full awal $\leq \mathrm{Q}$ full akhir dan $\mathrm{V}$ full akhir $0.6-3 \mathrm{~m} / \mathrm{dtk}$

$$
\begin{gathered}
Q a b=80 \% \times Q \text { air minum } \\
q r=80 \% \times \text { Qair minum rata }- \text { rata } \\
Q \text { min }=0.2 \times P E^{0.8} \times q r \\
Q m d=5 \times P E^{0.8} \times f_{m d} \times q r
\end{gathered}
$$

Saluran

$$
\text { Qsaluran }=\left(\frac{L}{1000}\right) \times q \text { infiltrasi }
$$

$$
Q \text { peak }=Q m d+Q \text { inf.saluran }+Q \text { inr.surface }
$$

$$
Q \text { full awal }=\text { Qpeak } /\left(\frac{\text { Qpeak }}{\text { Qfull }}\right)
$$

$$
D \text { hitung }=\sqrt{\frac{4 x\left(\frac{\text { Qfull awal }}{\text { Vfull asumsi }}\right)}{\pi}}
$$

$$
\begin{gathered}
V \text { full }=\frac{1}{n} \times R^{2 / 3} \times S^{1 / 2} \\
Q \text { full akhir }=\frac{1}{4} \times \pi \times(\text { D.rancangan })^{2} \times V \text { full } \\
V \text { peak }=\left(\frac{V \text { peak }}{V \text { full }}\right) \times V \text { full }
\end{gathered}
$$

*) $\mathrm{V}$ peak/V full didapatkan dari grafik design of main sewers dengan $\mathrm{d} / \mathrm{D}=0.8$

$$
\begin{aligned}
& V w=V \min +\sqrt{\frac{g(A g \cdot \overline{d g})-(\text { amin } \cdot \overline{d m i n})}{A m i n}\left(1-\left(\frac{A m i n}{A g}\right)\right)} \\
& Q g=V w(A g-A \min )
\end{aligned}
$$

$$
\begin{gathered}
D \min =\left(\frac{D \text { min }}{D \text { full }}\right) \times D \\
\text { Vmin }=\left(\frac{\text { Vmin }}{V \text { Vfull }}\right) \times \text { Vfull }
\end{gathered}
$$

18) Elevasi tanah (ET) dibagi mejadi dua, yaitu ET manhole 1 (Us) dan ET manhole 2 (Ds)

$$
\begin{gathered}
E D S(U s)=E T(U s)-4.61-D \\
E D S(D s)=E T(U s)-(S x L) \\
E M A=E D S(U s)+\left(\frac{d}{D} \times D\right) \\
E M A(D s)=E D S(D s)+\left(\frac{d}{D} \times D\right)
\end{gathered}
$$

EMA (Ds) perlu ditambahkan dengan selisih diameter agar tidak terjadi arus balik aliran.
$\mathrm{Pn}=$ jumlah penduduk tahun ken

Po $=$ jumlah penduduk tahun dasar

$\mathrm{Tn}=$ tahun ke-n

To = tahun dasar

$\mathrm{r}=$ laju pertumbuhan penduduk

$\mathrm{P} 1$ = jumlah penduduk pada

tahun awal proyeksi

P2 = jumlah penduduk pada

tahun akhir proyeksi

$\mathrm{T} 1=$ tahun awal proyeksi

$\mathrm{T} 2=$ tahun akhir proyeksi

$\mathrm{n}=$ jumlah interval

$\mathrm{Q}=$ debit $(\mathrm{l} / \mathrm{dtk})$

Qab = debit air buangan (1/dtk)

$\mathrm{qr}=$ debit air buangan rata-rata

(1/dtk)

Qmin $=$ debit minimum (1/dtk)

$\mathrm{PE}=$ penduduk ekivalen (jiwa)

Qmd = debit maksimum (1/dtk)

$\mathrm{fmd}=1.25-2$

$\mathrm{Cr}=0.1-0.3$

$\mathrm{L}=$ panjang pipa $(\mathrm{m})$

Qpeak = debit puncak (1/dtk)

$\mathrm{D}=$ diameter pipa $(\mathrm{mm})$

$\mathrm{V}=\operatorname{kecepatan}(\mathrm{m} / \mathrm{dtk})$

$\mathrm{n}=$ koef. kekasaran Manning

$\mathrm{R}=$ jari-jari hidrolis (m)

$\mathrm{S}=$ slope

$\mathrm{Vw}=$ kec. aliran penghantar

(m/dtk)

$\mathrm{g}=$ gravitasi $(\mathrm{m} / \mathrm{dtk} 2)$

$\mathrm{Ag}=$ luas penampang basah (m2)

$\overline{d g}=2 / 5 \mathrm{x} \mathrm{dg}$

$\mathrm{dg}=$ kedalaman titik berat air pd kedalaman berenang

$\overline{d m ı n}=2 / 5 \mathrm{x} \mathrm{dmin}$

dmin $=$ kedalaman titik berat air pd kedalaman minimum

Qg = debit penggelotoran

(m3/dtk)

$\mathrm{L}=$ panjang saluran $(\mathrm{m})$

EDS = elevasi dasar saluran (m)

EMA = elevasi muka air (m) 


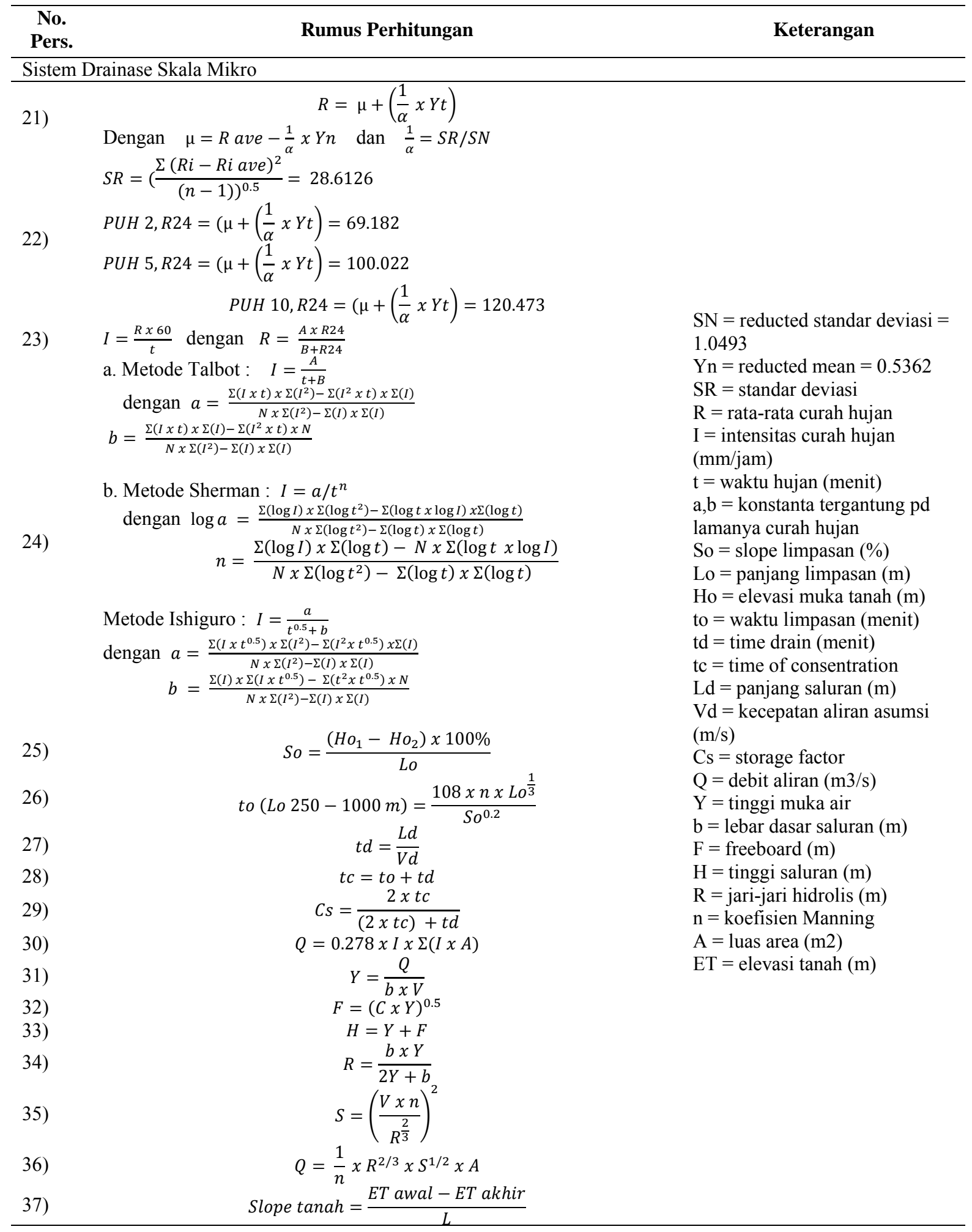


Lampiran 3. Peta sistem penyaluran air limbah domestik Kota Bogor.

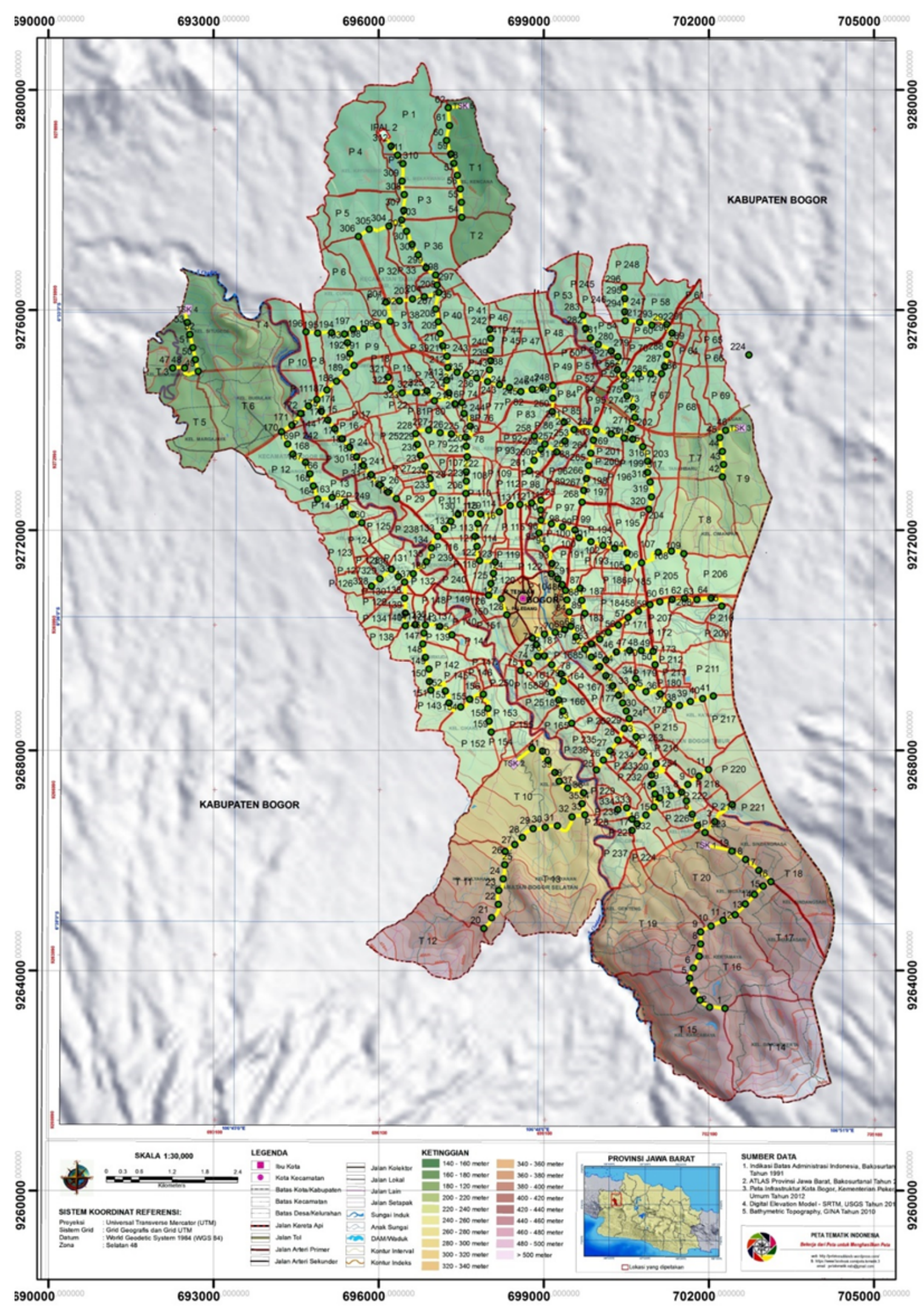


Lampiran 4. Peta sistem drainase skala mikro Kota Bogor.

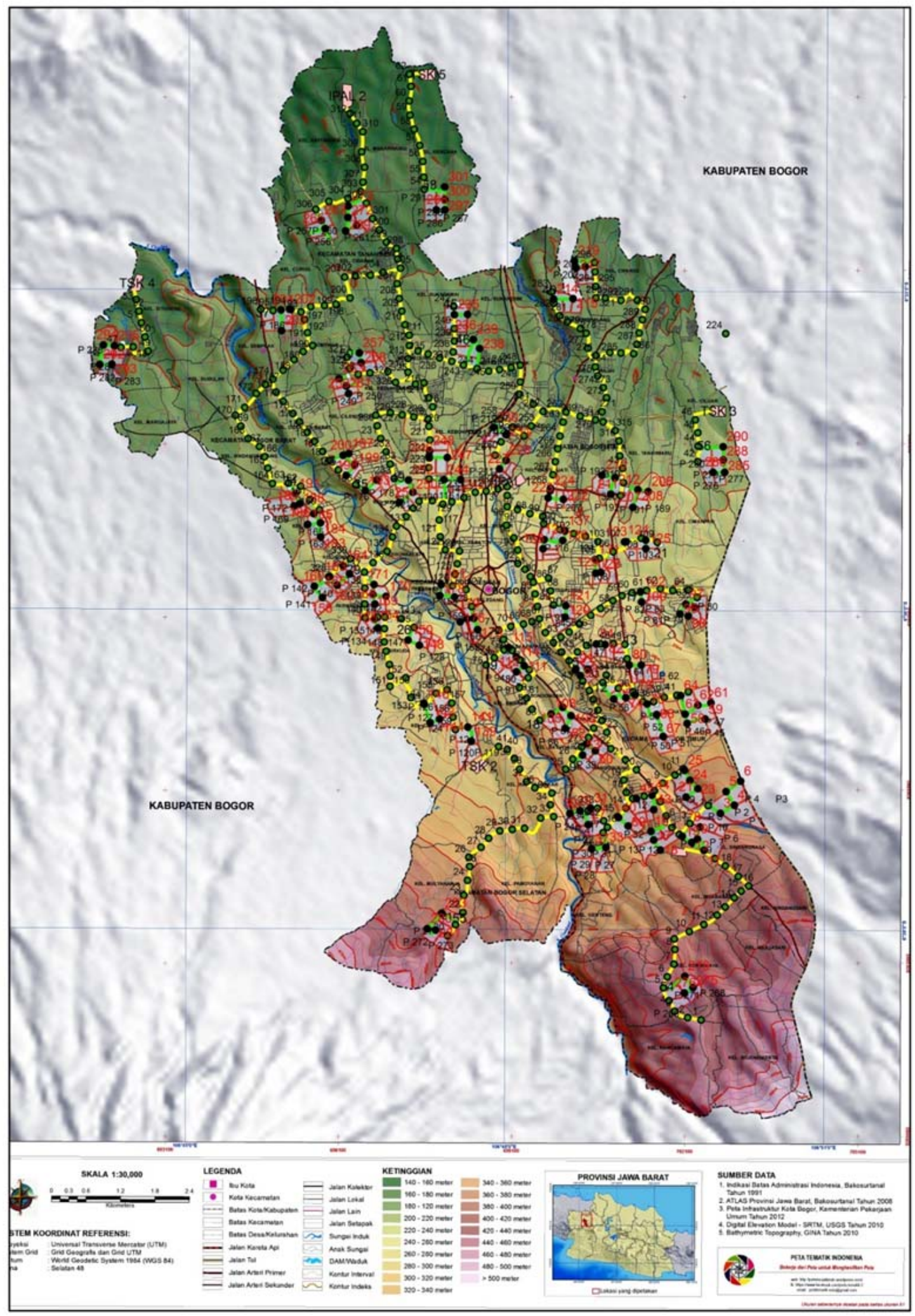

